\title{
Electromagnetic susceptibility of wireless relay against surge
}

\begin{abstract}
The examination of electromagnetic susceptibility of electronic devices is an important part of the process of design, development and construction of the electronic device. Surge is one of the types of electromagnetic interference and all the electronic devices must be tested on this type of interference according to international standards. Surge often occurs at the atmospheric disturbances such as lightning or at disorders in the energy of the high voltage network. The surge can cause failure of devices or even its permanent damage or destruction, in case the electronic device has insufficient electromagnetic immunity.
\end{abstract}

Streszczenie. Udary często powodowane są prze wyładowania elektryczne i zakłócenia w sieci elektrycznej. Mogą one powodować zakłócenia pracy przekaźników a nawet ich uszkodzenie. W pracy przedstawiono badania wpływu udarów na pracę bezprzewodowych przekaźników. Kompatybilność elektromagnetyczna przekaźników bezprzewodowych

Keywords: Electronic systems, Electromagnetic susceptibility, Immunity, Surge.

Słowa kluczowe: kompatybilność elektromagnetyczna, udary, przekażniki bezprzewodowe

\section{Introduction}

Electromagnetic compatibility is a multidisciplinary department, which includes in its theoretical foundations of whole electrical engineering. Development of the electronics, especially a microprocessor technology, radically changed not only the concept and methods of use of electronic devices, but also demands for their installation and location. The processes of electronic devices such as the transmission of information, automatic processing of information and data recording are exposed to disturbing influences originating from multiple sources of interference. The disturbing influence of environment is manifest by undesirable bonds, interfering background noise, the resonance and transient phenomena. This can induce not only malfunction of electronic devices, but also a distortion or depreciation the transmission of information and recording data. In some extreme cases, the disturbing influence can cause the destruction of sensitive electronic circuits. Restriction interference on the one hand and increasing immunity of electronic systems and ensure their electromagnetic compatibility on the other hand is becoming one of the key factors in the development of electronic equipment at present. [1]

\section{Terminology, definitions and normalization in the field} of EMC

Electromagnetic compatibility (EMC) is the ability of equipment, system or device to function satisfactorily in its electromagnetic environment. In this environment are present sources of electromagnetic signals, which can have adversely effect. Electromagnetic signals can have natural or artificial character. Another part of EMC is the ability of equipment, system or device to function without introducing intolerable electromagnetic disturbances to anything in that environment.

Electromagnetic interference (EMI) is the process of transmitting signal, which is generated by the source of interference into the disturbed system. This signal is transmitted by the electromagnetic binding. Particular it is about the identification of sources of interference, their description and measurement of interference signals, identification of parasitic transmission paths and establishing of actions primarily in the resources of interference and their transmission paths. EMI deals with the causes of disturbance and their removal.

Electromagnetic susceptibility (EMS) (immunity to a disturbance) is the ability of a device, equipment or system to function without degradation in the presence of an electromagnetic disturbance. They must work without error or with clearly defined of possible influence. EMS deals with the technical measures which increase electromagnetic immunity of receivers. EMS is focused on removing the consequences of interference, without removing their causes. [2]

By reason of proposal and realization of testing workplace of electromagnetic susceptibility for testing surges on security alarm systems we should be familiar with the following terms and abbreviations:

- EUT - abbreviation of the equipment under test;

- Surge is a transient wave of electrical current, voltage or power spreading along a line or a circuit and characterized by a rapid increase followed by a slower decrease of the voltage;

- I\&HAS (Intrusion and hold-up systems) is a complex set of technical equipment which solve the protection against unauthorized entry to the building.

In the Czech Republic among the basic standards used for testing electromagnetic compatibility we include sets of standards which have a designation of CSN IEC 1000 and CSN EN 61000. Interference immunity is especially devoted to set of standards CSN EN 61000-4.

For the purposes of this paper, we follow the particular standards:

- CSN EN 61000-4-5 ed.2. Electromagnetic compatibility (EMC) - Part 4-5: Testing and measurement techniques Surge immunity test;

- CSN EN 50130-4 ed. 2. Alarm systems - Part 4: Electromagnetic compatibility - Product family standard: Immunity requirements for components of fire, intruder, hold up, CCTV, access control and social alarm systems.

\section{Test equipment and sets}

Surge occurs at the atmospheric disturbances (lightning), at switching processes or at disorders in the energy of the high voltage network, where the voltage surge with energy up to $50 \mathrm{~J}$ gets into the low voltage distribution. Surge is a broadband high-energy pulse whose frequency range is from $1 \mathrm{kHz}$ to $1 \mathrm{MHz}$. On the basis of impedance of the source and the EUT, we distinguish two types of surge:

1. Impulse voltages - the input impedance of the power supply the terminals of the EUT is large compared with the output impedance of the source;

2. Impulse current - the input impedance is relatively small.

In both cases, the surge generates at the terminals of the EUT. [2] 
The standard CSN EN 61000-4-5 ed. 2 [3] covers requirements for immunity equipment against the direct surges. The aim of the standards CSN EN 61000-4-5 ed. 2 is to create a general and reproducible basis for evaluating the immunity of electrical and electronic equipment exposed to surges.

For the realization of the tests immunity to surge is used hybrid generator - CWG (Combination Wave Generator). This generator can generate impulse voltage and also impulse current. A voltage impulse is carried in a condition of an open-circuit and a current impulse in a condition of a short-circuit, these conditions are different in a rise time and a descent pulse.

The standard CSN EN 61000-4-5 ed. 2 defines two types of combination wave generator:

- generator 10/700 $\mu$ s - used for input/output EUT intended to be connected symmetric communication lines,

- generator 1,2/50 $\mu s$ - used in other cases, especially for input / output EUT intended to connect the power supply lines and for the short signal lines.

Generator used for measuring EMS - AXOS5 from Haefely EMC Technology, is a generator of the type 1,2/50 $\mu \mathrm{s}$. Simplified circuit diagram of the combination wave generator $1,2 / 50 \mu \mathrm{s}$ is shown in the Fig. 1 .

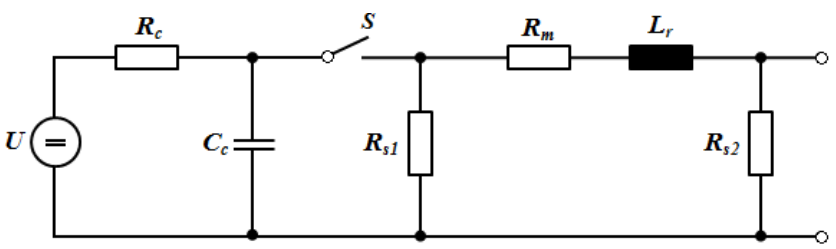

Fig. 1 Simplified circuit diagram of the CWG $(1,2 / 50 \mu \mathrm{s}-8 / 20 \mu \mathrm{s})$

The main elements of the combination wave generator $1,2 / 50 \mu$ s are:

- high voltage source $(U)$,

- charging resistor (Rc),

- energy storage capacitor (Cc),

- high voltage switch (S),

- rise time shaping inductor ( $\mathrm{Lr}$ ),

- pulse duration shaping resistors (Rs1 a Rs2),

- impedance matching resistor (Rm).

Impulse voltages denoted $1,2 / 50 \mu$ s (Fig. 2 a)), i.e. the rise time of the open-circuit voltage (the time duration between when an instantaneous value of pulse is $10 \%$ and then $90 \%$ ) takes $1,2 \mu$ s and the time for half the open-circuit voltage (pulse gradually reaches by $10 \%$, then $100 \%$ to $50 \%)$ ) takes $50 \mu \mathrm{s}$.

Impulse current denoted $8 / 20 \mu$ s (Fig. 2 b)), i.e. the rise time of the short-circuit current takes $8 \mu$ s and the time for half the short-circuit current takes $20 \mu \mathrm{s}$.
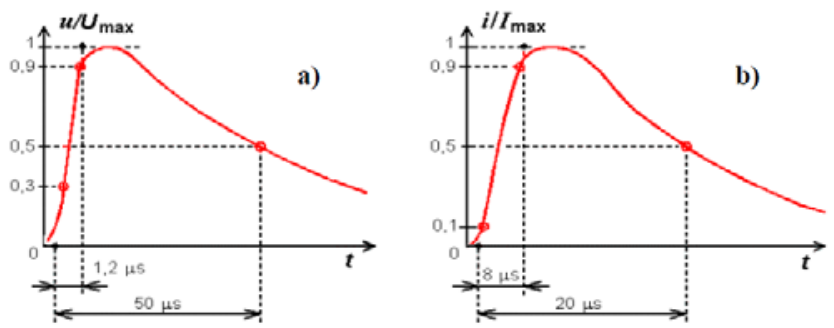

Fig. 2 The test signal - a) open-circuit voltage surge, b) short-circuit current surge [2]
The test suite for testing EMC according to the standard CSN EN 61000-4-5 ed.2 contains the following basic test equipment:

- equipment under test (EUT),

- auxiliary equipment $(\mathrm{AE})$ when required,

- cables - of specified type and length,

- coupling/decoupling networks,

- combination wave generator,

- decoupling network/protection devices,

- ground reference - connection to a ground reference is only required when the EUT is normally installed with a ground reference connection. [3]

\section{Proposal and realization of the workplace}

Based on the standards CSN EN 61000-4-5 ed.2 [3] and CSN EN 50130-4 ed. 2 [4]. We performed a test for immunity to surges in the selected device. This device was a component of I\&HAS - wireless relay AC82.

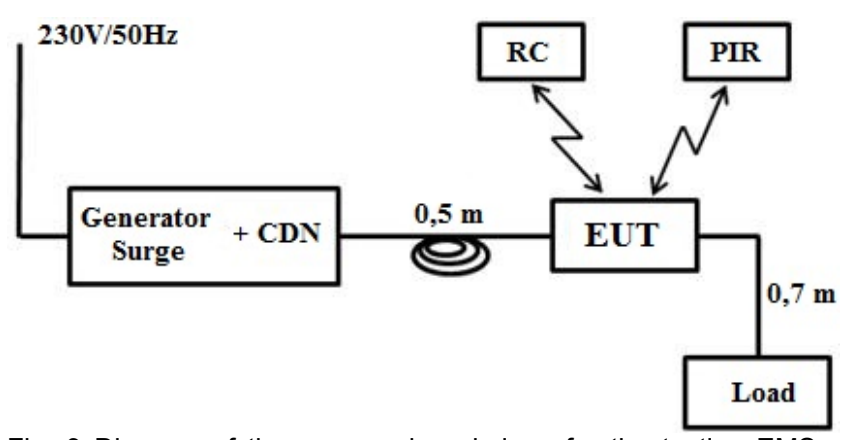

Fig. 3 Diagram of the proposed workplace for the testing EMS Surge

Description of the testing set up shown in the Fig. 3:

- Generator surge + CDN (coupling/decoupling network) testing device AXOS5;

- EUT - wireless relay AC82;

- Load - 15W light bulb;

- $R C$ - remotely control RC86W;

- $\quad$ IIR - PIR detector JA83P.

The proposed workplace was placed on a wooden table $80 \mathrm{~cm}$ high, with the upper surface of $150 \times 100 \mathrm{~cm}$. Table was placed on the ground reference plane and on the entire surface of the table was also placed ground reference plane. EUT and all cables connected with the EUT were placed as described in the standard CSN EN 61000-4-5 ed. 2 on an insulating underlay of $10 \mathrm{~cm}$ above the ground reference plane and at a distance of $0.5 \mathrm{~m}$ from the other conductive structures (e.g. walls of the room). Testing device AXOS5 was powered from the network $230 \mathrm{~V} / 50 \mathrm{~Hz}$ and all the test set was properly grounded.

The parameters of the testing device AXOS5 from Haefely EMC Technology satisfy the requirements arising from the provision set of standards CSN EN 55016 Specification for radio disturbance and immunity measuring apparatus and methods. On the tested wireless relay AC82 was connected load in the form of $15 \mathrm{~W}$ light bulb and EUT wirelessly communicate with the PIR detector and remotely control.

At the beginning of the testing was on the EUT performed functional tests and EUT was subsequently connected to the proposed test workplace. During testing the device was monitored whether or not the EUT occur status change at any of the tested surges and after each test was verified full functionality of the EUT. According to the criteria for meeting the requirement in accordance with CSN EN 50130-4 ed. 2 it must not experience any damage, malfunction or change of status of the EUT during testing. 
Only the flashing indicator was permissible if it does not occur any residual change in the EUT.

The tested wireless relay AC82 was during the test EMS in the active mode and also in the off mode. Peak value of the voltage was set to $\pm 0.5 \mathrm{kV}$ and $\pm 1.0 \mathrm{kV}$ according to the standard. The number of the surges was set to 20 with the frequency 5 seconds. The wireless relay AC82 meets the requirements given in the standards, because during testing, there were no changes in status, faults or damage to the EUT (Table 1).

Table 1 Record of the measurements of the EUT

\begin{tabular}{|c|c|c|c|c|}
\hline $\begin{array}{c}\text { Number of } \\
\text { measurements }\end{array}$ & $\begin{array}{c}\text { Peak } \\
\text { voltage } \\
{[\mathrm{kV}]}\end{array}$ & $\begin{array}{c}\text { Regime } \\
\text { of the } \\
\text { EUT }\end{array}$ & $\begin{array}{c}\text { Change } \\
\text { during } \\
\text { testing }\end{array}$ & $\begin{array}{c}\text { Functionality } \\
\text { of the EUT }\end{array}$ \\
\hline 1. & +0.5 & OFF & none & $\begin{array}{c}\text { full } \\
\text { functionality }\end{array}$ \\
\hline 2. & +0.5 & ON & none & $\begin{array}{c}\text { full } \\
\text { functionality }\end{array}$ \\
\hline 3. & -0.5 & OFF & none & $\begin{array}{c}\text { full } \\
\text { functionality }\end{array}$ \\
\hline 4. & -0.5 & ON & none & $\begin{array}{c}\text { full } \\
\text { functionality }\end{array}$ \\
\hline 5. & +1.0 & OFF & none & $\begin{array}{c}\text { full } \\
\text { functionality }\end{array}$ \\
\hline 6. & +1.0 & ON & none & $\begin{array}{c}\text { full } \\
\text { functionality }\end{array}$ \\
\hline 7. & -1.0 & OFF & none & $\begin{array}{c}\text { full } \\
\text { functionality }\end{array}$ \\
\hline 8. & -1.0 & ON & none & $\begin{array}{c}\text { full } \\
\text { functionality }\end{array}$ \\
\hline
\end{tabular}

\section{Conclusion}

In the supply network surges of the type of switching transients related for example with to switching of capacitor battery, the associated switching activities, changes in network load, the resonance circuit in conjunction with the switching devices (e.g. thyristors) or with different network failures (e.g. short circuits). Surges of the type of atmospheric transients often related to the lightning strikes.

Within security alarm systems electromagnetic compatibility is important especially in the cases of mutual integration of alarm and non-alarm applications. With regard to stability of function of security systems cannot come to changes in their condition, to damage of their components or essential features by the effect of electromagnetic interference (false alarms, communication disruption, damage due to overvoltage, distortion of image etc.). [5]

The tested wireless relay AC82 meet the test requirements for EMS surge described in the standards CSN EN 61000-4-5 ed.2 and CSN EN 50130-4 ed. 2. After completion of the prescribed tests wireless relay was subsequently tested for higher surges. Surges have the peak value of $\pm 1,5 \mathrm{kV}$ and the number of the surges was set to 10 with the frequency 5 seconds. We have not revealed any change in the state of the EUT during the test.

In another test, we set the peak value up to $+2,0 \mathrm{kV}$, the number of the surges was set to 5 with the frequency 5 seconds. After the second surge loud cracking sound was heard and there is a change in the load connected to the wireless relay AC82 - 15W light bulb has switched off. We subsequently ended the test, we examined the wireless relay and check its functionality. During the test, there was a change in the state wireless relay, but after the test, the device returns to functional status without our intervention.

\section{Acknowledgments}

This work was supported by the Ministry of Education, Youth and Sports of the Czech Republic within the National Sustainability Programme project No. L01303 (MSMT7778/2014) and also by the European Regional Development Fund under the project CEBIA-Tech No. CZ.1.05/2.1.00/03.0089 and Internal Grant Agency of Tomas Bata University under the project No. IGA/FAI/2015/043

\section{Authors}

Ing. Hana Urbancokova, Ing. Jan Valouch Ph.D., doc. Mgr. Milan Adamek, Ph.D.

Address: Tomas Bata University in Zlin, Faculty of Applied

Informatics, nam. T.G.Masaryka 5555, 76001 Zlin

Czech Republic

Emails:

urbancokova@fai.utb.cz

valouch@fai.utb.cz

adamek@fai.utb.cz

\section{REFERENCES}

[1] E. VACULIK and P. VACULIKOVA, Electromagnetic compatibility of electrotechnical systems: A practical guide to technology limitations HF electromagnetic interference, 1st ed., Grada Publishing, Prague, 1998, p. 487. ISBN 80-716-9568-8.

[2] J. SVACINA, Electromagnetic compatibility: Principles and comment, University of Technology, Brno, 2001, p. 156. ISBN 80-214-1873-7.

[3] CSN EN 61000-4-5 ed. 2: Electromagnetic compatibility (EMC) - Part 4-5: Testing and measurement techniques - Surge immunity test, The Czech Office for Standards, Metrology and Testing, Prague, 2007.

[4] CSN EN 50130-4 ed. 2: Alarm system. Part 4: Electromagnetic compatibility - Product family standard: Immunity requirements for components of fire, intruder, hold up, CCTV, access control and social alarm systems, The Czech Office for Standards, Metrology and Testing, Prague, 2012.

[5] J. VALOUCH, "Electromagnetic compatibility alarm systems testing and measurement of electromagnetic parameters," in: Security magazine, Ed. No. 107, 3/2012. Security Media, Prague, 2012, pp. 24-29. ISSN 1210-8273. 